\section{SOI: $1.1 /$ TAS DOI: $10.15863 /$ TAS International Scientific Journal Theoretical \& Applied Science}

p-ISSN: 2308-4944 (print) e-ISSN: 2409-0085 (online)

Year: 2017 Issue: 04 Volume: 48

Published: $30.04 .2017 \quad$ http://T-Science.org
Ruzi Rabievich Komilov

Researcher

Samarqand Regional Institute of Retraining and Advanced training Workers of Public Education

Samarqand, Uzbekistan

SECTION 30. Philosophy

\title{
AESTHETIC COMPONENT OF WEDDING CEREMONIES OF THE UZBEK PEOPLE
}

Abstract: In this article some moments of one of the most important ceremonies in the life of every Uzbek - the wedding are considered. This ceremony in Uzbekistan is interesting for its special features, customs and traditions. This feast is accompanied by various rituals, in which a large number of relatives and friends of the groom and the bride's family are received.

Key words: Uzbek people, wedding ceremony, nikokh, kelin salom, folklore, fatih-tui, kelin tui, katlama tuyi, tobok zhuntish, kelin tushdi, campyr uldi, tukkiz tobok.

Language: English

Citation: Komilov RR (2017) AESTHETIC COMPONENT OF WEDDING CEREMONIES OF THE UZBEK PEOPLE. ISJ Theoretical \& Applied Science, 04 (48): 87-89.

Soi: http://s-o-i.org/1.1/TAS-04-48-15 Doi: crossef https://dx.doi.org/10.15863/TAS.2017.04.48.15

\section{Introduction}

Uzbek wedding is necessarily a long and serious process, which is prepared long before the celebration. It all starts with finding the right bride for your adult son. To this end, through familiar parents, they gather all the necessary information about the girl: about her social status, level of education and upbringing, her ability to lead a household.

After a suitable candidate is found, the guy's parents send matchmakers to the house to the bride. The task of the matchmakers is special; it is they who are responsible for the first impression to draw a conclusion about both the girl's family and the bride herself. A sharp eye of the matchmaker inspects the level of order and cleanliness in the house, carefully watching the girl's ability to look after the guests.

Usually the matchmaker is greeted with cordiality, invited to the table, singing tea. However, quite often the party of the bride from the first time gives the consent to give out the daughter. Usually only for the third time, when the parties come to an agreement, as a positive response - they break a cake. This ceremony is called "non-syndicate" and means the final consent of the parents of the bride.

After this, the date of the engagement is "fatihtui". The engagement is celebrated a little more with a smaller scope than the wedding itself. On this day, the groom's party presents the bride's mother with various gifts. They bring money, sweets, beautiful fabrics, sheep meat.

\section{Materials and Methods}

In general, the cost of a wedding banquet is borne by the groom's side. But in some areas, for example in Tashkent, the parents of young people agree in advance on the distribution of expenses on the occasion of the wedding event.

On the day of the wedding celebration in the house of the bride early in the morning prepare a festive pilaf, which is invited exclusively to men.

In the afternoon, the groom, dressed up in a festive costume, which, as a rule, he buys the side of the bride, comes to the house of his chosen one. In some areas, for example, in Bukhara, a gold embroidery chapan is worn over the costume, which is taken off before leaving the registrar with the bride. Modern Uzbek brides wear white wedding dresses for official registration. The face must be covered with a veil, so that the young girl is not jinxed.

Usually, before registering with the Registry Office, young people undergo a religious ceremony of marriage "nikokh". The Imam reads the appropriate prayers, and the young give promises to respect each other throughout the marriage life. During this ritual, the newlyweds wear national festive clothes. 
While escorting a young woman from her home, she is sent a full set of dowry, which includes everything necessary for the first period of family life: kurpacha, towels, and household utensils.

After the wedding banquet, coming to the groom's home, the young people walk around the fire three times before they enter the house, which means their cleansing and the beginning of the marriage life.

The next day, after the wedding night, the bride is not disturbed. She may not even leave her room, for the first three days she is considered a guest. A couple of days the bride is taken out for the ritual "kelin salom". On this day guests come and give the bridegroom various gifts, and as a token of gratitude the girl should bow to the guests in the belt.

These are the main rites that are observed in almost all areas of the country. In different regions, post-wedding activities can take weeks. But their main goal remains the same - to provide young people a happy and prosperous life.

It is known that in the territory of our country for some hundreds of years, original folklore traditions were formed that reflected the systems of national values existing in each region, folklore performance. From this point of view, the genre elements of the Uzbek wedding ritual are distinguished by their varied rituals, customs and traditions. Folklore and ethnographic records made in the Ishtikhan district of the Samarkand region confirm this diversity. Records made by the famous scientist Muzayan Alavia testifies that in the 60s of the 20th century, In the Ishtikhan district of the Samarkand region there was a wedding ceremony, on the eve of the "kelin tui" (wedding at the bride) from her house to the groom's house forty cakes (patyr), forty thin tortillas (katlama) cooked in butter, two fine thin cakes), Two tortillas (patyr). Having received these thin tortillas (katlama), the groom's parents, slaughtering a ram or bull, celebrated the ceremony of "katlama tuyi" - a wedding dedicated to a thin cake (pancakes). For this purpose, neighbors, close relatives met. Swatam-women who brought katlama were given expensive silk fabrics. In each bowl from katlama put 5-6 kg. Fruit and cut material.

This wedding ceremony was called "tobok zhuntish" (exchange of dishes), and it was repeated twice between the parents of the bride and groom.

During the second time the dishes were exchanged, various sweets were sent from the groom's side: fruits, sweets, cookies and also expensive silk material, a mirror, rings, earrings. And also together with all this send a bull or a ram. After receiving these gifts, the wedding ritual was performed by the bride, "damage to the bishots" (measurement of the material)", "porcha bichuv"(material cut).

On the day of this ritual, part of the gifts received from the groom were distributed to the bride's relatives.
In the Ishtikhan district, close friends of the groom are called "kuevboshlar (companions of the groom)", and the closest among them is "kuyevboshlatar" (best man). On the day of the ritual "kelin tushdi" (bride's arrival) the groom's friends were received in a separately decorated room, and the daughter-in-law of the bride treated them. The first dish to which the groom's friends were treated was called scrambled eggs, and the dishes in which they brought the dish were called "tanish tobok" (familiar dishes). After the groom's friends ate the eggs, they threw money into the dishes. After the feast, the ritual "Nikoh kiyish" (wedding) was held. After the religious ceremony, the daughter-in-law of the bride dressed the groom, put on a robe (kuyov chapan), skullcap, waist shawl and escorted by the groom's friends led to the middle of the courtyard where the fire was burning. The bridegroom three times walked around him and bowed to all those present, then the groom and his friends went to the room where the bride's dowry was. At the door the groom's friends gave the daughter-in-law of the bride a piece of material with the words "eshik iluva" (ask permission to enter the room). The snows of the bride, in turn, poured at the foot of the groom a carpet material. Behind the threshold of the bride's room lay an old woman, portraying the image of a barking dog. This ritual was called "it irillatarar" (dog barking) is performed with the goal that the groom has many children, so that evil spirits will bypass them and. And the other old woman was lying on the bed in the middle of the room, depicting the deceased, and this ritual was called "campyr uldi" (the old woman died). After receiving the gift from the groom's friends, the old woman "came to life."

The groom's friends lined up in a row and bowed to him several times. After that, permission was given to sit down. Everyone sat, except the groom and his best man, After the groom's motherin-law said the following words: "The calf's my heifer is now yours (belongs to you)", the groom and his driver got in. The dastarkhan was covered with all sorts of dishes: pancakes, katlama, bugirsak (buns), flat cakes, samsa, brisket, lamb. This ceremony is called "tukkiz tobok" (nine kinds of dishes). The sweetest piece of brisket was given to the groom, who hid behind the backs of friends. Friends of the groom, having tasted of nine dishes everything that remained, was wrapped in belbog (a waist shawl) and threw money into empty utensils. After that, each of the friends of the groom and himself handed out a handkerchief out of his dowry. All friends, except the groom and the chauffeur, left the room.

One of the daughter-in-law came up to the kuyovboshlatar, elbowed the hole in the kurpache and the kuyovboshlatar filled this hole with money. After that, the daughter-in-law turned to him with the words: "Buzarimni Bering currents" (show signs of 


\begin{tabular}{l|lrl|l|ll} 
& ISRA (India) & $=\mathbf{1 . 3 4 4}$ & SIS (USA) & $=\mathbf{0 . 9 1 2}$ & ICV (Poland) & $=\mathbf{6 . 6 3 0}$ \\
Impact Factor: & ISI (Dubai, UAE) $=\mathbf{0 . 8 2 9}$ & PUHL (Russia) $=\mathbf{0 . 2 3 4}$ & PIF (India) & $=\mathbf{1 . 9 4 0}$ \\
& GIF (Australia) & $\mathbf{0 . 5 6 4}$ & ESJI (KZ) & $=3.860$ & IBI (India) & $=\mathbf{4 . 2 6 0}$
\end{tabular}

love). Kuyovboshlatar gives her, and she, in turn, gives him a shirt "yataka" and a waist shawl. After that, all the dowry of the bride was prepared for export.

According to the ethnographer G. Tosheva, in the Kasan and Chirakcha districts of the Kashkadarya region this ritual is called "fossa filling". According to this ceremony, when the groom came into the room to pick up the bride, one of the old women from the bride's side formed a pit in the kurpache and screamed "the hole was not filled." After the groom filled this hole, he was allowed to remove the dowry of the bride. In the Ishti Khan fog on the wedding day, the bride was not at her home, but together with her friends "hid" in one of the houses of her neighbors. The snows brought the bride into the house, put her on the kurpach (mattress) and gave it to the baby's hand and went out to the groom in this way.

\section{Conclusion}

This shows that the traditional genres of the Uzbek wedding rite in each region, in each fog have their own, local characteristics and differ very significantly in details. Wedding rituals are diverse since the days of Uzbek folklore and ethnography, it is expressed in many specific features. Their presence since ancient times has a significant specificity. On the basis of the wedding rite in each region there are their customs and rituals reflecting the worldviews of the local population differ from each other depending on the region. Therefore, the list of Uzbek wedding folklore is diverse.

\section{References:}

1. Ugvinovich DY (1975) Obryady: za i protiv. M.

2. Genkik DM (1975) Massovye prazdniki. - M.

3. Suhanov IZ (1976) Obychai, tradicii i preemstvennost' pokoleniy. - M.

4. Sarsenbaev NS (1974) Obychaya i tradicii v razvitii. - Alma-Ata.

5. Tul'ceva LA (1985) Sovremennye prazdniki i obryada narodov SSSR. - M.

6. Gashurov G (1986) Umumhalk urf-odatlari halk kalbida. - Tashkent.

7. Lobacheva NP (1975) Razlichnye obryadovye kompleksy $\mathrm{v}$ svadebnom ceremoniale narodov
Sredney Azii i Kazahstana. // Domusul'manskie verovaniya i obryady v Sredney Azii., M.

8. Lobacheva NP (1978) K istorii slozheniya instituta svadebnoy obryadnosti (na primere kompleksov svadebnyh obychaev i obryadov narodov Sredney Azii i Kazahstana). // Sem'ya i semeynye obryady u narodov Sredney Azii i Kazahstana., M..

9. Lobacheva NP (1981) Svadebnyy obryad kak istoriko-etnograficheskiy istochnik. Na primere horezmskih uzbekov // SE, 1981, № 2.

10. Jabborov I (2004) O`zbeklar an`anaviy turmushi va madaniyati, $\mathrm{T}$. 